Dunja Rađenović ${ }^{1 *}$, Đurđa Kerkez ${ }^{1}$, Dragana

Tomašević Pilipović ${ }^{1}$, Sebastian Baloš ${ }^{2}$,

Aleksandar Došić ${ }^{3}$, Slavko Smiljanić3 ${ }^{3}$ Dejan Krčmar ${ }^{1}$

${ }^{1}$ University of Novi Sad, Faculty of Sciences, Department for Chemistry, Biochemistry and Environmental Protection, Novi Sad, Serbia, 'University of Novi Sad, Faculty of Technical Sciences, Department of Production Engineering, Novi Sad, Serbia, ${ }^{3}$ University of East Sarajevo, Faculty of Technology, Zvornik, Republic of Srpska, Bosnia and Herzegovina

Scientific paper ISSN 0351-9465, E-ISSN 2466-2585 UDC:620.122.2:622.717 doi: $10.5937 /$ ZasMat1704556R

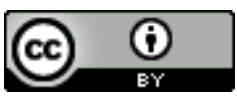

Zaštita Materijala 58 (4)

$556-563(2017)$

\title{
Long-term performance of stabilised/solidified polluted sediment in terms of metal leachability and matrix characterization
}

\begin{abstract}
Sustainable and economically feasible polluted sediment treatment is gaining more and more importance. Stabilization/solidification (S/S) technologies are widely used for treatment of sediment and possibilities of using low-cost and readily available materials and binders are increasingly being examined. This work is concerned with aquairing more data about long-term performance of this kind of treatment in therms of metal leaching and microstructural cnaracterization when treating sediment with fly ash and lime. Extraction potential of metals and the effectiveness of the $S / S$ treatment applied, together with compliance with national legislative, were performed by using Toxicity Characteristic Leaching Procedure - TCLP and The German standard leaching test - DIN 3841-4 S4. Leaching test results showed that the applied S/S treatment was effective in immobilizing metals even after seven years of aging. Scanning electron microscope (SEM) and X-ray diffraction analysis confirmed that pozzolanic reactions took place during 28 days and continued along S/S mixture maturation. Compressive strength measurement further proved the treatment efficacy in terms of obtained matrix stability, which enables their subsequent use. It can be concluded that the S/S technique, with the usage abundant materials has a significant potential for treatment of metal polluted sediment.
\end{abstract}

Keywords: sediment, fly ash, leaching, stabilization/solidification, matrix characterization.

\section{INTRODUCTION}

Sediment can be defined as a solid phase of aquatic system, consisting of chemical, biochemical and biological deposits. It associates organic and inorganic contaminants by physical-chemical processes which can be present in aquatic systems [1]. Heavy metals, present in sediment, are harmful to the environment and human health. Therefore, it is necessary to identify and implement effective, economical remediation technologies to treat sediment which is contaminated with heavy metals in order to avoid risks and hazards in aquatic environment. One of proposed technologies includes the processes and techniques of stabilization and solidification (S/S) which present the treatment of hazardous and other wastes.

${ }^{*}$ Corresponding author: Dunja Rađenović

E-mail: dunja.radjenovic@dh.uns.ac.rs

Paper received: 02. 06. 2017.

Paper corrected: 12. 09. 2017.

Paper accepted: 22. 09. 2017.

Paper is available on the website:

www.idk.org.rs/journal
Stabilization is a technique that reduces the potential for hazardous waste. It converts the contaminants into less soluble and less mobile, and therefore less accessible. Different chemical additives, as lime, fly ash and Portland cement can help in establishing of the stabilization. Solidification is a technique that compact waste into a monolithic solid matrix of high structural integrity. The main objective of solidification is converting the waste into a form that is easier to operate and dispose. Also, it should minimize the harmful potential of reducing waste area that is in contact with the environment [2].

The last few years, the alkali-activated fly ash is often used for the treatment of stabilization/ solidification [3-5]. The solid aluminosilicate precursors, such as the slag or fly ash, are being formed from the burning of coal in thermal power plants in the alkali activation. They start to dissolve in the alkaline solution, usually sodium hydroxide or sodium silicate, which results a three-dimensional, reticular structure of aluminosilicate [6].

Pozzolanic properties of fly ash, as well as its binding capacity, make it useful for the production 
of cement, building materials and concrete products. The most frequent components of fly ash are $\mathrm{SiO}_{2}, \mathrm{Al}_{2} \mathrm{O}_{3}, \mathrm{CaO}$ and $\mathrm{Fe}_{2} \mathrm{O}_{3}$, which can be in the form of an amorphous and crystalline oxide or various minerals. The other important characteristics of fly ash which make it suitable for use as an adsorbent are particle size, porosity, water holding capacity and surface area [7].

$\mathrm{Ca}(\mathrm{OH})_{2}$ as additive for the synthesis of the fly ash based on geopolymers provides the formation of $\mathrm{C}-\mathrm{S}-\mathrm{H}$ gel which can improve the removal of contaminants, as well as to reduce the desorption [8]. Quartz, kaolinite, illite and sideraete are the most frequent mineral phases. Quartz and mullite are the crystalline constituents of fly ash with low contents of calcium, whereas quartz, $\mathrm{C}_{3} \mathrm{~A}, \mathrm{CS}$ and $\mathrm{C}_{4} \mathrm{AS}$ have a high content of calcium consists [8]. The use of lime represents probably one of the oldest techniques of stabilization. By adding a sufficient amount of lime pozzolanic reaction occurs between the minerals in the soil and calcium derived from the lime which in contact with water forms a cementitious compound with properties such as calcium silicate hydrate and calcium aluminate hydrate. These hydrates are also called by the abbreviations $\mathrm{CH}, \mathrm{CAH}, \mathrm{CSH}$ and $\mathrm{CASH}$, where $\mathrm{C}=\mathrm{CaO}, \mathrm{A}=\mathrm{Al}_{2} \mathrm{O}_{3}, \mathrm{~S}=\mathrm{SiO}_{2}$ and $\mathrm{H}=\mathrm{H}_{2} \mathrm{O}$ [9].

The aim of this paper was the treatment of contaminated sediment from the "Veliki Bački Canal" by the method of stabilization/solidification (S/S) using fly ash and lime as immobilization agents in certain combinations and quantities. Study included long-term performance characterization of obtained matrices.

\section{MATERIALS AND METHODS}

\subsection{Sample preparation}

The analyzed sediment was dried on $105{ }^{\circ} \mathrm{C}$, and then mixed with immobilization agents, in selected proportions, and finally compaction was performed according to ASTM D1557-00 procedure [10]. After that, the samples were preserved at $20^{\circ} \mathrm{C}$ in the sealed bags for 28 days. After 28 days, the monolithic samples were crushed and then subjected to the leaching experiments and further characterization. This step is repeated on the same mixtures that have been kept for seven years in laboratory conditions to determine the time impact. Samples were designated by capital letter F-fly ash and L-lime followed by a number that indicate the percentage of agent added in a mixture with polluted sediment.

\subsection{Leaching tests}

Leaching tests were performed on samples after 28 days of curing (F30-28D and F20L10-28D) as well as on the same mixtures after seven years (F30-7Y and F20L10-7Y).

\subsection{TCLP test (Toxicity Characteristic Leaching}

Procedure, USEPA metod 1311, 2003)

TCLP tests include the extraction of the waste material from $100 \mathrm{~g}$ sample placed in a 2 -liter extraction vessel and mixed with the extraction fluid. The samples were extracted at a liquid to solid (L/S) ratio of 20:1 in capped polypropylene bottles on a rotary tumbler at 30rpm for $18 \mathrm{~h}$. After 18 hours of stirring, the $\mathrm{pH}$ was measured in the extract which was filtered after that through a membrane $(0.45 \mu \mathrm{m})$ filter [11]. The filtrate was then preserved with nitric acid and then was analyzed for metal content by using AAS (Perkin Elmer AAnalyst ${ }^{\mathrm{TM}} 700$ ) or ICP-MS (Perkin Elmer Sciex Elan 5000) technique.

\subsection{The German standard leaching test - DIN 3841-4 S (DIN 3841-4 $S^{4}$; 1984)}

The German standard leaching test - DIN 3841-4 S $\mathrm{S}^{4}$, uses grained sample with particle size smaller than $10 \mathrm{~mm}$ [12]. Leaching is performed with deionised water at 10:1 L/S ratio (l kg-1), during the testing period of $24 \mathrm{~h}$. After shaking the final $\mathrm{pH}$ value was measured and a sample was filtered through a membrane ( $0.45 \mathrm{um})$ filter. After that, the filtrate was preserved with nitric acid and then was analyzed for metal content by using AAS (Perkin Elmer AAnalyst TM 700) or ICP-MS (Perkin Elmer Sciex Elan 5000) technique.

\subsection{Characterization on $S / S$ mixtures}

To better understand metal immobilization and other micro structural properties, X-ray diffraction (XRD) and scanning electron microscope (SEM) analyses were performed on the prepared monolithic matrices. The monolithic matrix was crushed and dried, ground to powder and then subjected to XRD and SEM analyses. SEM photographs of the samples were carried out by QUANTAX 70 EDS System TM3000 - Bruker, Germany. For the XRD data collection Rigaku MiniFlex 600 was used. Compressive strength was determined by measuring the resistance of undisturbed samples in $\mathrm{MPa}$. The results are interpreted according to Patel and Pandey (2012) and del Valle-Zermeño et al. (2013) [13, 14].

\section{RESULTS AND DISCUSSION}

The results of TCLP test of treated samples after 28 days and after 7 years are displayed in Table 1.

Results are diversified regarding whether the leaching increased or decreased over time for different metals. Generally, leached concentrations of all metals for both mixtures of different age are rather low and far below the limit values according to the Regulation on categories, testing and classification of waste [15]. Therefore, it can be 
concluded that these materials do not posse toxic properties and can be considered safe and nonhazardous.

\section{Table 1. Leached metal concentrations according to TCLP procedure}

Tabela 1. Izlužene koncentracije metala prema TCLP proceduri

\begin{tabular}{|c|c|c|c|c|c|}
\hline \multirow{2}{*}{ Time } & $\mathrm{Cr}$ & $\mathrm{Ni}$ & $\mathrm{Cu}$ & $\mathrm{Cd}$ & $\mathrm{Pb}$ \\
\cline { 2 - 6 } & \multicolumn{5}{|c|}{$\mathrm{mg} / \mathrm{F} 3$} \\
\hline & 0.022 & 0.478 & 0.073 & 0.053 & 0.086 \\
\hline $28 \mathrm{D}$ & 0.056 & 3.388 & 0.705 & 0.028 & 0.024 \\
\hline $7 \mathrm{Y}$ & \multicolumn{5}{|c|}{$\mathrm{F} 20 \mathrm{~L} 10$} \\
\hline & 0.021 & 1.010 & 0.123 & 0.069 & 0.094 \\
\hline $28 \mathrm{D}$ & 0.006 & 2.278 & 1.781 & 0.022 & 0.257 \\
\hline $7 \mathrm{Y}$ & 5 & 20 & 25 & 1 & 5 \\
\hline Limit values* & 5 &
\end{tabular}

*Limit values for metals according to TCLP procedure

The results of DIN 3841-4 $S^{4}$ test on treated samples are presented in Table 2 . These results were interpreted by using the national regulations for the classification and testing of waste [15], as well as by comparing it with the values prescribed by the European Union [16]. In a mixture of sediment and fly ash concentrations of $\mathrm{Cr}$ and $\mathrm{Pb}$ has reduced after 7 years, while the concentrations of $\mathrm{Ni}, \mathrm{Cu}$ and $\mathrm{Cd}$ have been slightly increased. F30 mixture based on the concentrations of $\mathrm{Cr}, \mathrm{Ni}, \mathrm{Cu}$, and $\mathrm{Cd}$ represents a non-hazardous waste, while according to the $\mathrm{Pb}$ concentration represents inert waste.

Table 2. Leached metal concentrations according to DIN 3841-4 $S^{4}$ test

Tabela 2. Izlužene koncentracije metala prema DIN 3841-4 $S^{4}$ testu

\begin{tabular}{|c|c|c|c|c|c|}
\hline \multirow{2}{*}{ Time } & $\mathrm{Cr}$ & $\mathrm{Ni}$ & $\mathrm{Cu}$ & $\mathrm{Cd}$ & $\mathrm{Pb}$ \\
\cline { 2 - 6 } & \multicolumn{5}{|c|}{$\mathrm{mg} / \mathrm{kg}$} \\
\hline & 0.220 & 0.603 & 1.972 & 0.007 & 2.661 \\
\hline $28 \mathrm{D}$ & 0.600 & 1.420 & 1.104 & 0.054 & 0.060 \\
\hline $7 \mathrm{Y}$ & \multicolumn{5}{|c|}{$\mathrm{F} 20 \mathrm{~L} 10$} \\
\hline & 0.470 & 7.267 & 1.614 & 0.001 & 2.924 \\
\hline $28 \mathrm{D}$ & 0.070 & 8.470 & 18.36 & 0.013 & $<0.059$ \\
\hline 7 Y & 1 & 1 & 2 & 0.005 & 1 \\
\hline $\begin{array}{c}\text { LAGA Z2* } \\
\text { values }\end{array}$ & 0.5 & 0.4 & 2 & 0.04 & 0.5 \\
\hline $\mathrm{A}^{*}$ & $10-$ & $10-$ & $50-$ & $1-5$ & $10-50$ \\
\hline$B^{*}$ & 70 & 40 & 100 & $1-5$ \\
\hline
\end{tabular}

$A^{*}$ - Maximum allowed concentration of accepting waste as inert $\mathrm{L} / \mathrm{S}=10 \quad(\mathrm{l} / \mathrm{kg}) ; \mathrm{B}^{*}$ - Maximum allowed concentration of accepting waste as non-hazardous $\mathrm{L} / \mathrm{S}=10(\mathrm{l} / \mathrm{kg})$; * $\mathrm{Z} 2$ upper recommended value of usage
The concentrations of $\mathrm{Cr}, \mathrm{Cd}$ and $\mathrm{Pb}$ have decreased after 7 years in F20L10 mixture, and this mixture is characterized as the inert waste in terms of the concentrations of these three metals after seven years. Based on the concentrations of $\mathrm{Ni}$ and $\mathrm{Cu}$ in the same mixture, it is classified as non-hazardous after 7 years of applied S/S treatment. Also, both mixtures meet LAGA criteria, determined by German National Working Group on Waste [17], for the concentrations of $\mathrm{Cr}$ and $\mathrm{Pb}$.

SEM images enabled structural microanalysis of the observed part of the sample surface (Figure 1). Images indicate on creating denser structures with addition immobilization agents in comparison with raw sediment sample. In samples after 28 days there are noticeable spherical structures originating from fly ash addition. Over the years mixtures became more compact indicating on pozzolanic reactions taking place and creating discernible metal - bearing phases. Silica gel and C-S-H gel appears as porous fibers whereas calcite appears as equant grains $[18,19]$.
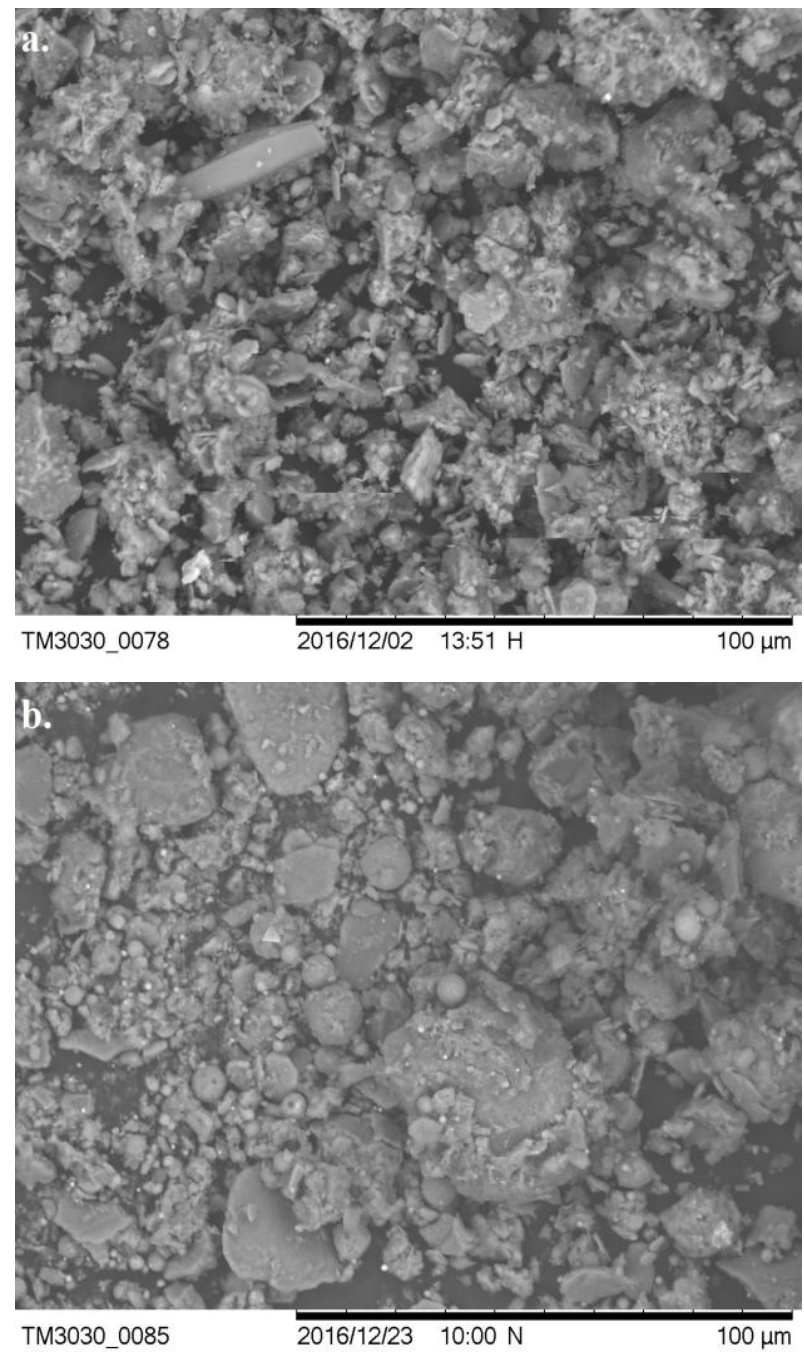

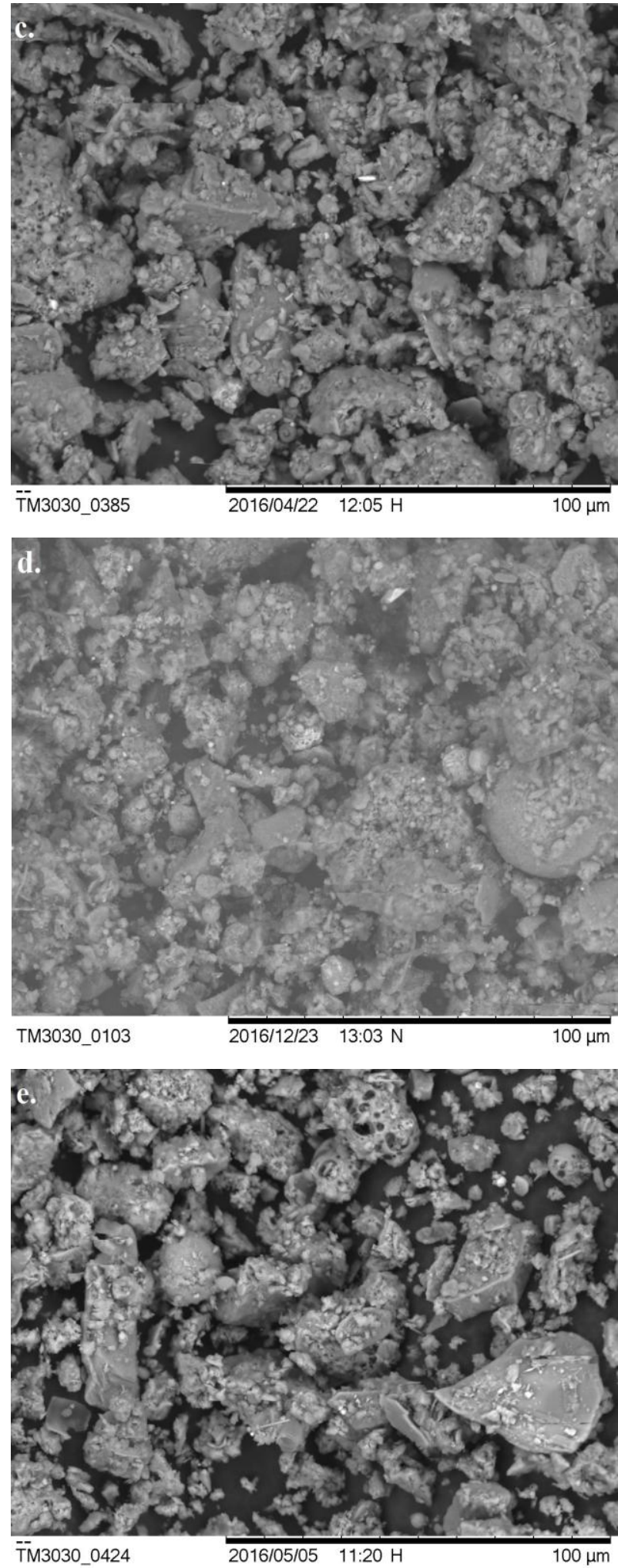

Figure 1. The morphology selected samples obtained by SEM analysis: a) raw sediment sample, b) F3028D, c) F30-7Y, d) F20L10-28D, e) F20L10-7Y

Slika 1. Morfologija odabranih S/S smeša dobijena SEM analizom: a) sirov uzorak sedimenta, b) F3028D, c) F30-7Y, d) F20L10-28D, e) F20L10-7Y
X-ray diffraction is a non-destructive method which determines the composition of samples, precisely, fractions of amorphous and crystalline phases, phase transformations. Figure $2(a, b)$ shows the XRD spectra of polluted sediment with fly ash as immobilization agent after 28 days and after 7 years of applied S/S treatment. Calcium silicate hydrate gel (CSH) is amorphous and cannot be detected by XRD. The quarts reflection are detected at $29.5^{\circ} 2 \theta$ in the mixture after 28 days of the applied treatment, while in the mixture after 7 years the calcite is detected at $29.5^{\circ}$ and $39.5^{\circ} 2 \theta[19]$.

Except these compounds, in the mixture after 28 days of aging, muscovite, phengite, enstatite and ferrosilite are also present. The mixture after 7 years, beside quartz and calcite, contains muscovite, illite, ferrosilite, dolomite and clinoenstatite. The XRD spectra (Figure 2c, d) shows the sharp peaks of CA (calcite) at $29.5^{\circ}$ and $39.6^{\circ} 2 \theta$ in the 7 years matured sample containing $70 \%$ sediment with $20 \%$ fly ash and $10 \%$ lime. This shows that changes into the sediment significantly complicate the formation of $\mathrm{C}-\mathrm{S}-\mathrm{H}$, and similar compounds due to calcium complexation by organic matter as well as hindrances by heavy metals and salt content in the sediment [20]. In both mixtures the quartz with very sharp peaks at $20.8^{\circ}, 26.6^{\circ}, 50.1^{\circ}, 60.0^{\circ}$ and $67.8^{\circ} 2 \theta$ is mostly present. In the mixture after 28 days, phengite, enstatite, muscovite, ferrosilite and clinomimetite are also detected. After 7 years, except for calcite and quartz this sample comprises: phengite, dolomite, enstatite, filatovite, berlinite and muscovite.

Unconfined compressive strength (UCS) measures the resistance of monolithic or cohesive materials to stress and can be used in determination of the performance of $S / S$ materials. According to the EPA [21], S/S materials that are harder than $0.35 \mathrm{MPa}$ can be considered as $\mathrm{S} / \mathrm{S}$ treated wastes with sufficient compressive strength to be considered safe for disposal. Both mixtures achieved proposed compressive strength value which increased over time (Figure 3). Furthermore, compressive strength is determined by the quality of pore structure and cementitious materials.

This depends on the type and quantity of the constituents of the pore structure (hydratation products) and pozzolanic reactions which are included in the S/S mixtures. 


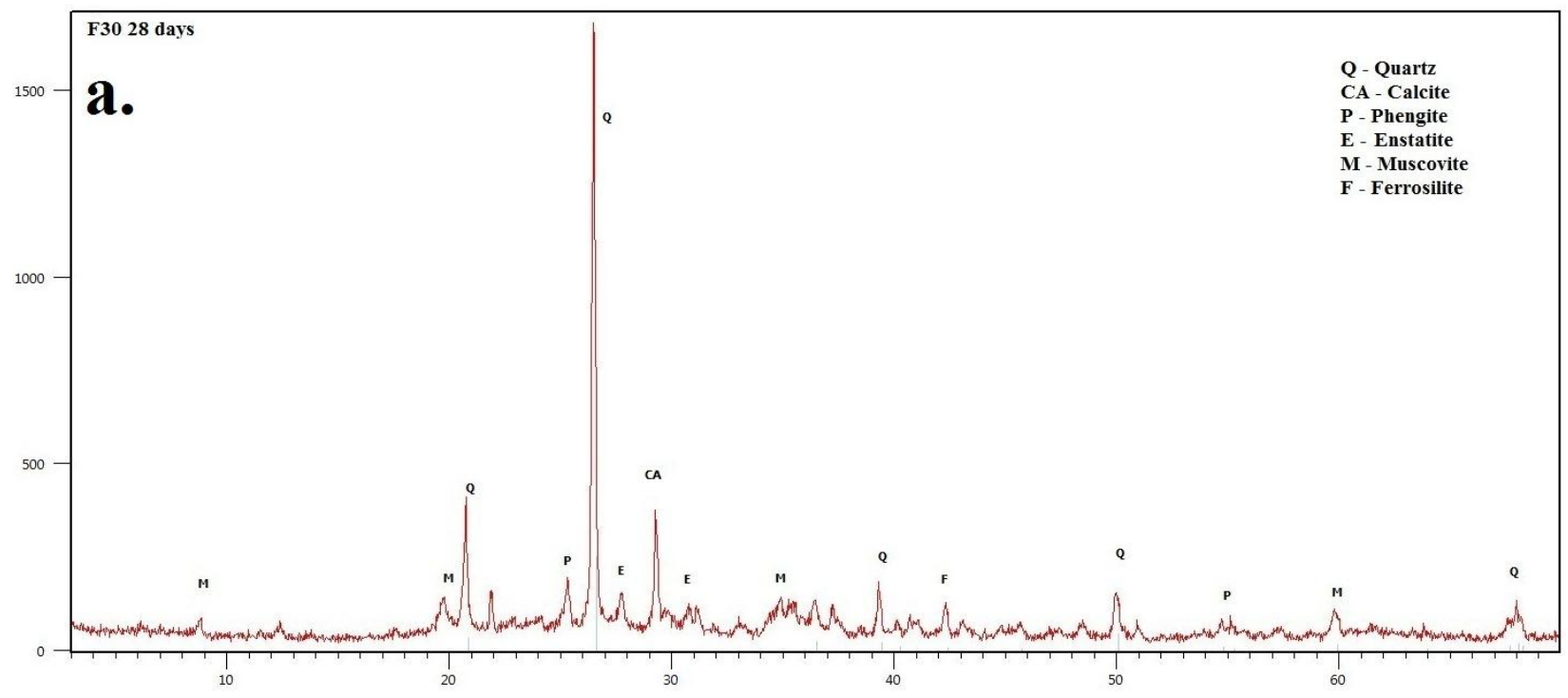

Position ['2Theta] (Copper (Cu))

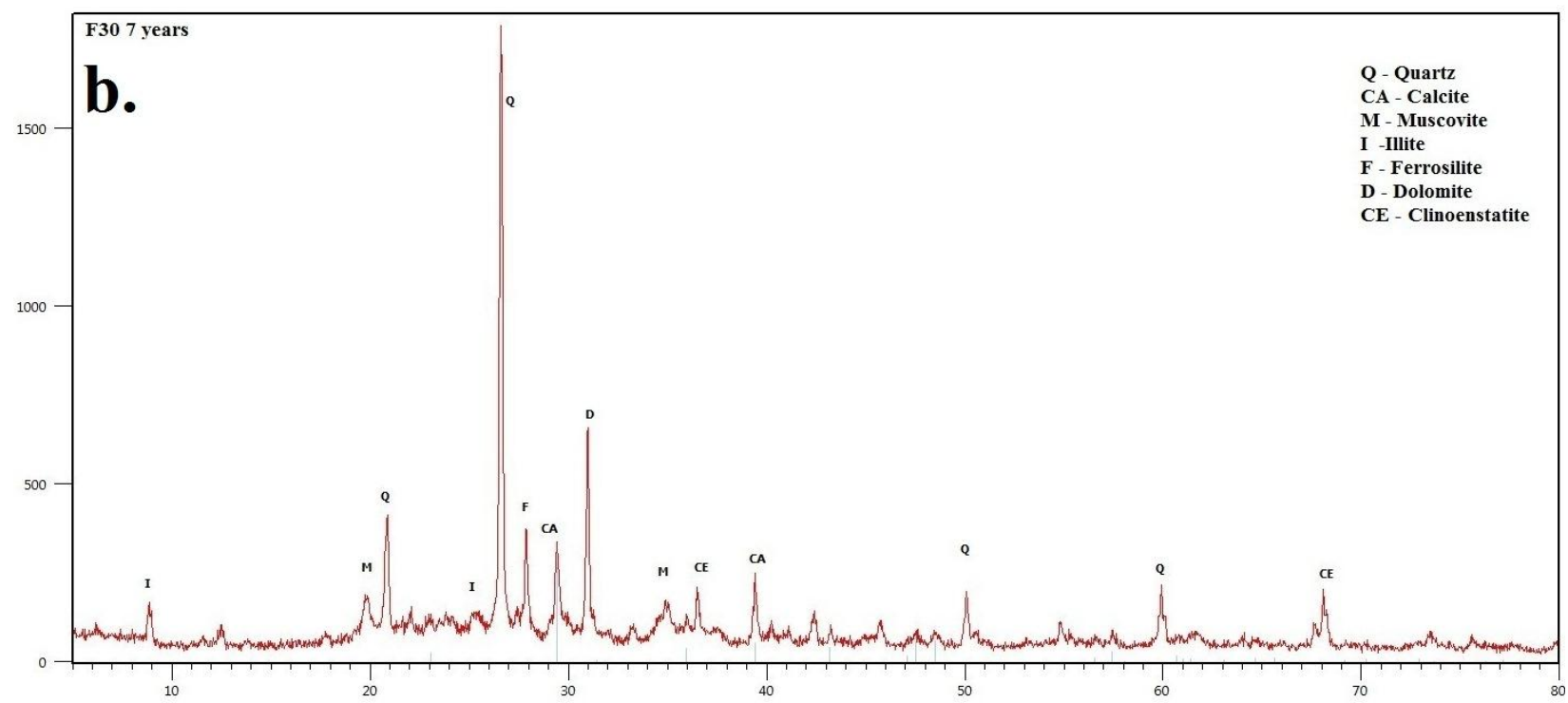

Position [2Theta] (Copper (CU))

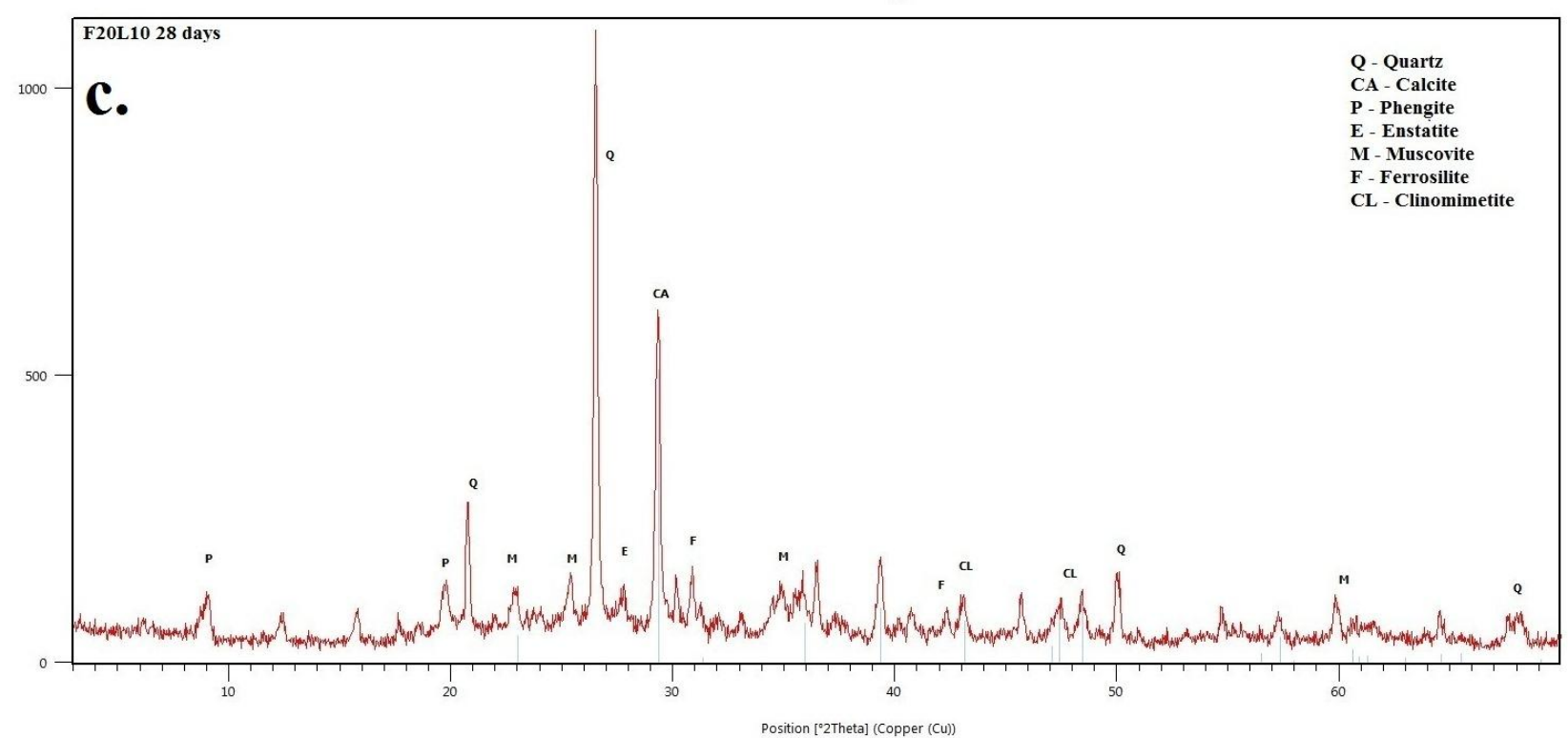




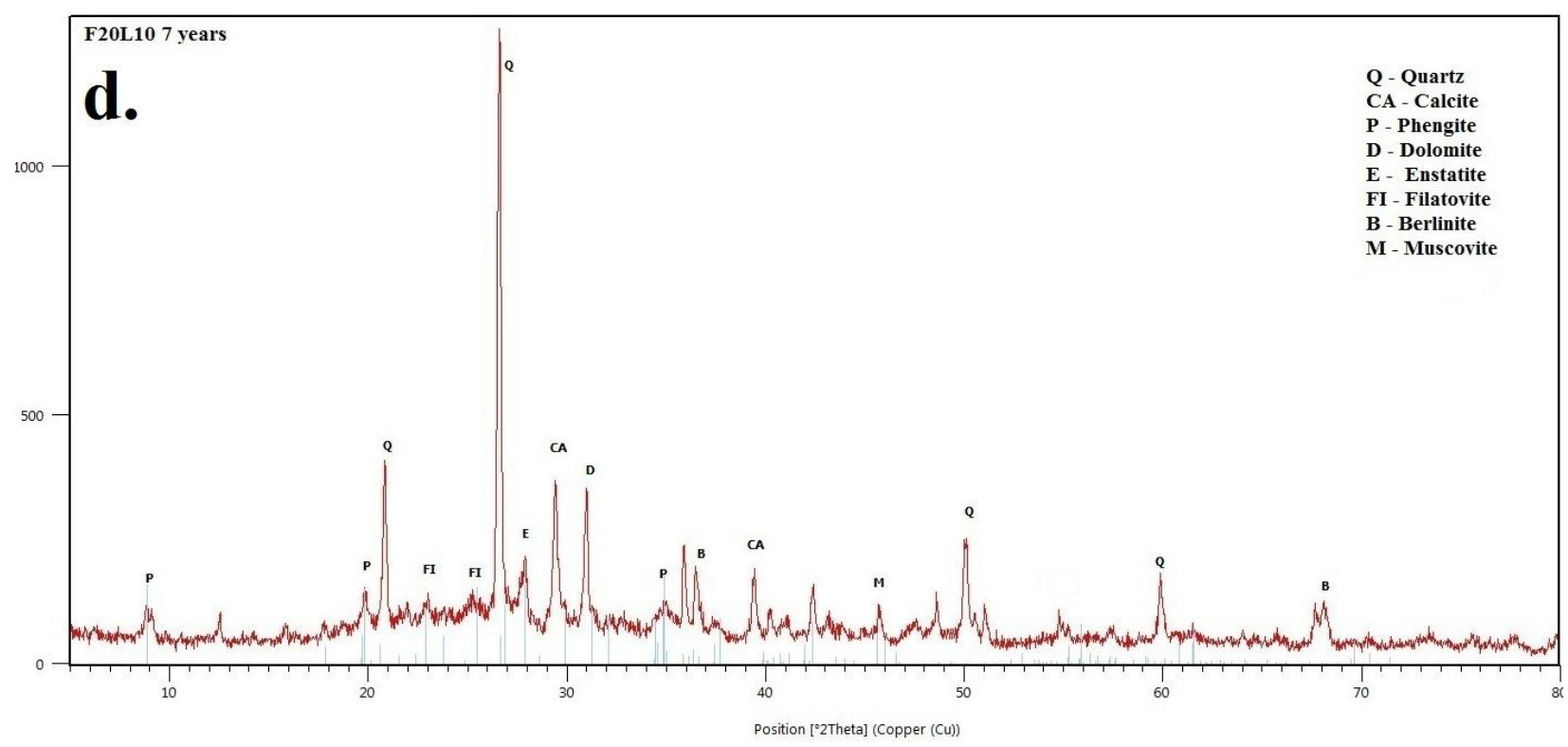

Figure 2. X-ray diffraction analysis (XRD) applied on S/S mixtures:

a) F30-28D, b) F30-7Y, c) F20L10-28D, d) F20L10-7Y

Slika 2. Difrakcija $X$ zracima $(X R D)$ primenjena na S/S smešama:

a) F30-28D, b) F30-7Y, c) F20L10-28D, d) F20L10-7Y

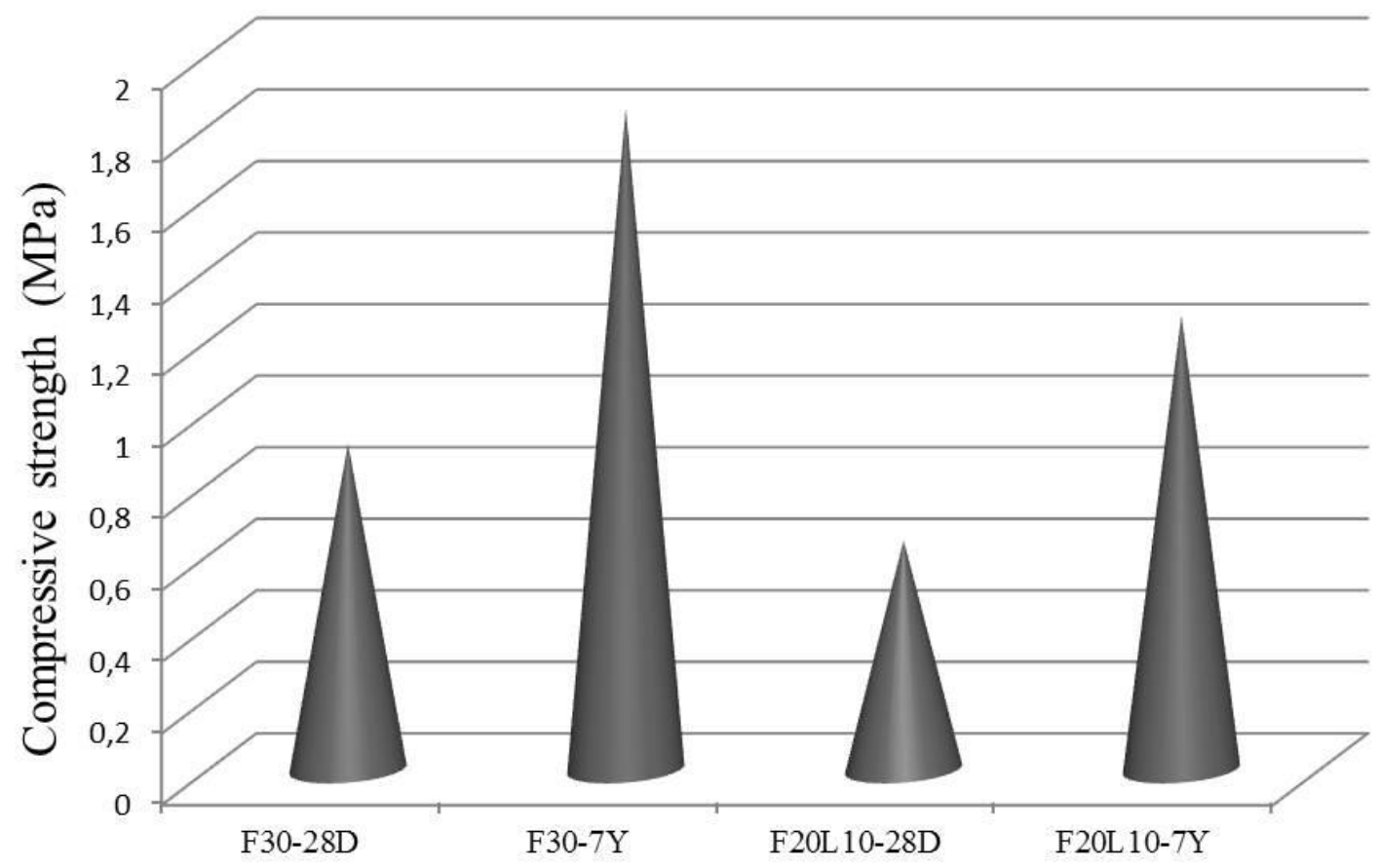

Figure 3. Compressive strength $(\mathrm{MPa})$ of obtained $S / S$ mixtures

Slika 3. Pritisna čvrstoća (MPa) ispitivanih $\mathrm{S} / \mathrm{S}$ smeša

\section{CONCLUSION}

The single-step leaching tests TCLP and DIN 3841-4 $S^{4}$ were applied to evaluate the extraction potential of metals in S/S matrices after 28 days of curing and 7 years of maturing and aging. The results showed that in all S/S samples there is a very limited leaching and leached metal concentrations are below the proposed regulatory limits. SEM and XRD analyses confirmed the formation of dense microstructure and pozzolanic 
compounds in tested S/S matrices especially after long-term maturing. From the aspect of compressive strength analysis, produced $\mathrm{S} / \mathrm{S}$ materials are viable for safe disposal and can also be considered as acceptable for "controlled utilization" as a bulk material. All results indicated that application of fly ash and lime, in this kind of remediation procedure, was successful in treating a waste containing a mixture of metals. Long-term performance can be considered rather satisfactory as matrices deterioration is at a low level. In addition usage of these two low-cost binders makes this kind of S/S treatment not only effective but also economically feasible.

\section{Acknowledgement}

This work has been produced with the financial assistance of the Ministry of Education, Science and Technological Development of the Republic of Serbia (III43005 and TR37004) and Provincial Secretariat for Higher Education and Scientific Research, AP Vojvodina (project No. 114-451. 2249/2016-02). The authors would like to thank BioSense Institute from Novi Sad, Serbia, for the use of measurement equipment and data analysis as well as to Goran Kitic, PhD for his dedicated support and assistance. Also authors would like to thank Prof. Srdjan Rakic, Department of physics, Faculty of Sciences, Novi Sad for his assistance in performing $X$-ray diffraction measurements.

\section{REFERENCES}

[1] T.Zoumis, A.Schimdt, L.Grigorova, W.Calmano (2001) Contaminants in sediments: remobilisation and demobilisation, The Science of the Total Environment, 266, 195-202.

[2] P.Santanu, K.Pak, N.Yuet (2006) Solidification /Stabilization of Organic and Inorganic Contaminants using Portland Cement: A Literature Review, Environmental Rewievs, 14 (4), 217-255.

[3] V.Nikolić, M.Komljenović, N.Marjanović, Z. Baščarević, R.Petrović (2014) Lead immobilization by geopolymers based on mechanically activated fly ash, Ceramics International, 40, 8479-8488.

[4] X.Guo, H.Shi, M.Xu (2013) Static and dynamic leaching experiments of heavy metals from fly ashbased geopolymers, Journal of Wuhan University of Technology-Mater. Sci. Ed, 28, 938-943.

[5] J.Zhang, J.L.Provis, D.Feng, J.S.J.van Deventer (2008) Geopolymers for immobilization of Cr6+, $\mathrm{Cd} 2+$ and $\mathrm{Pb} 2+$, Journal of Hazardous Materials, 157, 587-598.

[6] J.L.Provis, J.S. van Deventer (2009) GeopolymersStructures, Processing, Properties and Industrial Applications, Elsevier.

[7] M.Ahmaruzzaman (2010) A review on the utilization of fly ash, Progress in Energy and Combustion Science, 36, 327-363.
[8] Z.Li, S.Liu (2007) Influence of slag as additive on compressive strength of fly ashbased geopolymer, Journal of Materials in Civil Engineering, 19(6), 470474.

[9] N.Maubec, D.Deneele, G.Ouvrard (2017) Influence of the clay type on the strength evolution of lime treated material, Applied Clay Science, 137, 107114.

[10] ASTM D1557-00 (2000). Standard test method for laboratory compaction characteristics of soil using modified effort American Society for Testing Materials, Annual Book of ASTM standards: ASTM D1557-91, vol. 4.08. Philadelphia, P: ASTM.

[11] USEPA, Toxicity characteristic leaching procedure, method 1311 (2002). available at: www. EPA.gov/SW-846/1311.pdf.

[12] DIN 38414-4 (1984). Teil 4: Schlamm und Sedimente, Gruppe S., Bestimmung der EluierbarkeitmitWasser S4, BeuthVerlag, Berlin.

[13] H.Patel, S.Pandey (2012) Evaluation of physical stability and leachability of Portland Pozzolona Cement (PPC) solidified chemical sludge generated from textile wastewater treatment plants, Journal of Hazardous Materials, 207-208, 56-64.

[14] [14] R.del Valle-Zermeño, J.Formosa, J.M. Chimenos, M.Martínez, A.Fernández (2013) Aggregate material formulated with MSWI bottom ash and APC fly ash for use as secondary building material, Waste Management, 33, 621-627.

[15] [15] Official Gazzete, Ministry of Energy, Development and the Environment (2010) Regulation on categories, testing and classification of waste. The Official Gazette 56/2010.

[16] Official Journal of the European Communities, L11, Council Decision 2003/33/EC of 19 December 2002 establishing criteria and procedures for the acceptance of waste at landfills pursuant to Article 16 of and Annex II to Directive 1999/31/EC, (2003).

[17] LAGA. Cooperation of the German federal authorities on waste, Anforderungenan die stoffliche Verwertung von mineralischen Reststoffen/Abfällen; 5th September 1995, Berlin, Erich Schmidt Verlag, (1996).

[18] L.Wang, D.Tsang, C.Poon (2015) Green remediation and recycling of contaminated sediment by waste-incorporated stabilization/solidification, Chemosphere, 122, 257-264.

[19] Q.Chena, C.Hills, M.Yuan, H.Liu, M.Tyrer (2008) Characterization of carbonated tricalcium silicate and its sorption capacity for heavy metals: A micron-scale composite adsorbent of active silicate gel and calcite, Journal of Hazardous Materials, 153, 775-783.

[20] L.Wang, J.S.Kwok, D.Tsang, C.Poon (2015) Mixture design and treatment methods for recycling contaminated sediment, Journal of Hazardous Materials, 283, 623-632.

[21] Guide to disposal of chemically stabilized and solidified wastes (1982) U.S. EPA SW872. 


\section{IZVOD}

\section{DUGOROČNE PERFORMANSE STABILIZIRANOG/SOLIDIFIKOVANOG SEDIMENTA U POGLEDU IZLUŽIVANJA METALA I KARAKTERIZACIJE MATRIKSA}

Održivi i ekonomski izvodljivi tretmani zagađenog sedimenta postaju sve važniji. Tehnologija stabilizacije/solidifikacije (S/S) ima široku primenu u tretmanu sedimenta i mogućnosti korišćenja jeftinih i lako dostupnih materijala, a vezivni materijali se sve više ispituju. Ovaj rad se bavi praćenjem dugoročnih performansi u tretmanu izluživanja metala i mikrostrukturne karakterizacije pri tretiranju sedimenta sa letećim pepelom i krečom. Ekstrakcioni potencijal metala i efektivnost korišćenja S/S tretmana, izvršeni su korišćenjem TCLP testa izluživanja i standardnim nemačkim testom izluživanja (DIN 38414-4). Rezultati izluženih koncentracija metala pokazali su da je primenjeni S/S tretman bio efikasan u imobilizaciji metala čak i posle sedam godina starenja. Skenirajuća elektronska mikroskopija (SEM) i x-ray difrakciona analiza potvrdili su da se pozolanske reakcije dešavaju tokom 28 dana, kao i tokom sazrevanja S/S smeša. Merenje pritisne čvrstoće dodatno je dokazalo efikasnost tretmana u smislu dobijenih stabilnih matriksa, što omogućava njegovu kasniju upotrebu. Može se zaključiti da S/S tehnika, uz korištenje letećeg pepela i kreča, ima značajan potencijal za tretman sedimenta zagađenog metalima.

Ključne reči: sediment, leteći pepeo, izluživanje,stabilizacija/solidifikacija, karakterizacija matriksa.

Naučni rad

Rad primljen: 02. 06. 2017.

Rad korigovan: 12. 09. 2017.

Rad prihvaćen: 22. 09. 2017.

Rad je dostupan na sajtu: www.idk.org.rs/casopis

(c) 2017 Authors. Published by Inženjersko društvo za koroziju. This article is an open access article distributed under the terms and conditions of the Creative Commons Attribution 4.0 International license (https://creativecommons.org/licenses/by/4.0/) 